\title{
Climate warming in winter affects the coupling between phytoplankton and bacteria during the spring bloom: a mesocosm study
}

\author{
Hans-Georg Hoppe ${ }^{1, *}$, Petra Breithaupt ${ }^{1}$, Katja Walther $^{2}$, Regine Koppe $^{1}$, \\ Stephan Bleck ${ }^{1}$, Ulrich Sommer ${ }^{1}$, Klaus Jürgens ${ }^{2}$ \\ ${ }^{1}$ Leibniz Institute of Marine Science, IfM-GEOMAR, Düsternbrooker Weg 20, 24105 Kiel, Germany \\ ${ }^{2}$ Leibniz Institute of Baltic Sea Research (IOW), Seestrasse 15, 18119 Rostock, Germany
}

\begin{abstract}
The response of the phytoplankton and bacterial spring succession to the predicted warming of sea surface temperature in temperate climate zones during winter was studied using an indoor-mesocosm approach. The mesocosms were filled with winter water from the Kiel Fjord, Baltic Sea. Two of them were started at $\sim 2^{\circ} \mathrm{C}$ and the temperature was subsequently increased according to the decadal temperature profile of the fjord $\left(\Delta T 0^{\circ} \mathrm{C}\right.$, baseline treatment). The other mesocosms were run at 3 elevated temperatures with differences of $\Delta T+2$, +4 and $+6^{\circ} \mathrm{C}$. All mesocosms were exposed to the same light conditions. Timing of peak phytoplankton primary production (PP) during the experimental spring bloom was not significantly influenced by increasing temperatures, whereas the peak of bacterial secondary production (BSP) was accelerated by about $2 \mathrm{~d}$ per ${ }^{\circ} \mathrm{C}$. This suggests that, in case of warming, the spring peak of bacterial degradation of organic matter (in terms of BSP) would occur earlier in the year. Furthermore, the lag time between the peaks of PP and BSP (about $16 \mathrm{~d}$ for $\Delta T 0^{\circ} \mathrm{C}$ ) would diminish progressively at elevated temperatures. The average ratio between BSP and PP increased significantly from 0.37 in the coldest mesocosms to 0.63 in the warmest ones. Community respiration and the contribution of picoplankton $(<3 \mu \mathrm{m}$ fraction) to this also increased at elevated temperatures. Our results lead to the prediction that climate warming during the winter/ early spring in temperate climate zones will favor bacterial degradation of organic matter by tightening the coupling between phytoplankton and bacteria. However, if PP is reduced by warming, as in our experiments, this will not necessarily lead to increased recycling of organic matter (and $\mathrm{CO}_{2}$ ).
\end{abstract}

KEY WORDS: Bacterial secondary production - Baltic Sea - Climate change - Global warming - Marine bacteria $\cdot$ Mesocosm $\cdot$ Primary production $\cdot$ Respiration

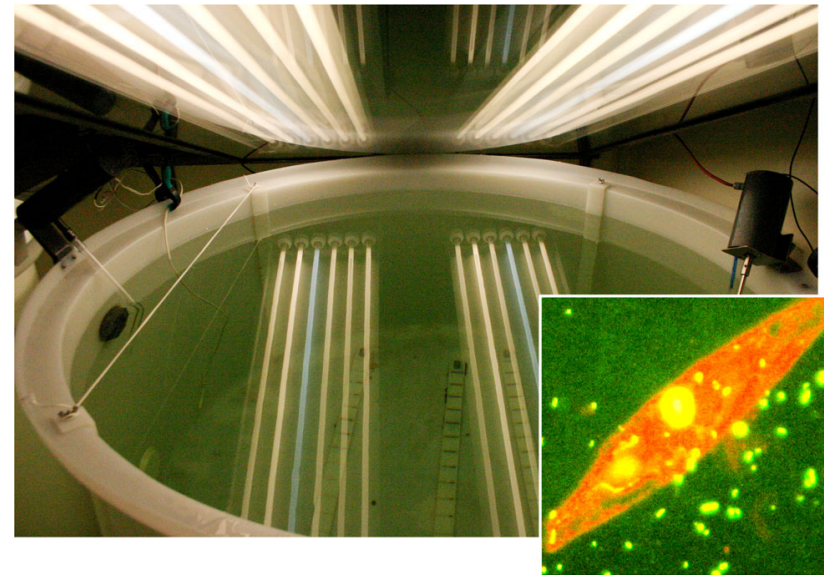

An indoor mesocosm used to determine the effect of warming on microbial communities. Inset: Recycling of organic matter inside the mesocosm is mediated by the interaction of phytoplankton and bacteria.

Photos: J. Harloff and R. Koppe (inset)

\section{INTRODUCTION}

Climate change is expected to increase water temperature in the temperate climate zone, particularly during winter and spring. An increase in the annual mean surface temperatures of 3 to $5^{\circ} \mathrm{C}$ during the $21 \mathrm{st}$ century ('business as usual' scenario) is predicted to cause a doubling of $\mathrm{CO}_{2}$ emissions. In winter, temperatures may increase by as much as 5 to $10^{\circ} \mathrm{C}$ (prediction for the years 2070 to 2100 compared to the reference period 1960 to 1990, IPCC 2001). Warming will have consequences for the aquatic food web in terms of its composition and the activity of its components at the different trophic levels (Beisner et al. 1997, Tian et al. 2003, Muren et al. 2005). Light-dependent phototrophic 
communities may be less affected by rising temperatures than heterotrophic microorganisms, which are mainly responsible for re-mineralisation of organic matter and respiration $\left(\mathrm{CO}_{2}\right.$ recycling). Furthermore, the coupling between $\mathrm{C}$-fixation by phytoplankton and organic C-utilisation by heterotrophic bacteria may be influenced with respect to the (relative) timing of these processes during the spring. The duration of the lag time between the peaks of the phytoplankton spring bloom and enhanced bacterial degradation is of great ecological importance. During a long lag time, dead phytoplankton may be lost by sinking, leading to a reduction of substrate for bacterial degradation in surface waters. In contrast, a close temporal coupling would favour instantaneous degradation of photosynthesised organic matter within the productive layer. In the latter case, re-mineralisation products remain in the photic zone and $\mathrm{CO}_{2}$ is recycled directly to the atmosphere. Finally, elevated temperatures during winter and spring could influence the efficiency of organic matter conversion by bacteria and other microbial loop organisms, as observed in permanently warm (sub)tropical regions (e.g. Hoppe et al. 2002, Kirchman et al. 2005). This would lead to a higher proportion of the total photosynthesised organic matter being metabolised and recycled by heterotrophic microorganisms.

The Baltic Sea is ideal for studying the effects of warming because its extension from north to south within the temperate climate zone creates pronounced temperature gradients during the spring. Information on the reaction of the biota to warm or cold winters could also be derived from long-term monitoring programs; however, it has to be taken into consideration that changes in other variables (e.g. hydrographic conditions) besides temperature may play a role. In the present study, the exclusive effects of temperature on microbes were analysed in an advanced indoor-mesocosm system, in which temperature and light were adjusted and varied according to environmental conditions. Plankton from the Kiel Fjord (western Baltic Sea) served as a model for moderately deep water basins, where the start of the spring bloom of phytoplankton precedes the onset of thermal stratification. Our hypothesis was that the different temperature sensitivities of food web components cause a loss of synchrony between the autotrophic substrate supply and heterotrophic substrate demand, with far-reaching consequences on the ecosystem, as predicted by the 'match-mismatch' theory (Cushing 1975, Edwards \& Richardson 2004).

The aim of our study was to investigate changes in the temporal coupling between primary production (PP) and bacterial growth (bacterial secondary production [BSP] and respiration) in response to the predicted warming of sea surface temperature in the temperate climate zone. For this purpose we used temperaturecontrolled indoor mesocosms and the natural, late winter plankton community from the Baltic Sea.

\section{MATERIALS AND METHODS}

Experimental set-up. The experiment was conducted from 7 February (38th day of the year) to 25 April (115th day of the year) 2005, as part of the AQUASHIFT program (Sommer et al. 2007). The cylindrical mesocosms were $1.4 \mathrm{~m}$ in diameter, $1 \mathrm{~m}$ deep (water level) and contained $1.4 \mathrm{~m}^{3}$ of water. A propeller was installed for gentle mixing of the water column. Smaller benthos chambers were linked to the mesocosms and served as a source of organisms from benthic resting stages. The dimensions of the mesocosms (surface:volume ratio) were close to those recommended by Berg et al. (1999) for optimal simulation of natural conditions. The mesocosms were filled simultaneously with unfiltered water from Kiel Fjord, which contained the over-wintering populations of phytoplankton, bacteria, protozoans and mesozooplankton larvae. Mesozooplankton (mainly copepods) obtained from net catches from the fjord were added at natural abundance (ca. 20 ind. $\mathrm{l}^{-1}$ ). The initial concentrations of nutrients in the mesocosms were representative of those in the fjord during winter: nitrate $21.49 \mu \mathrm{mol} \mathrm{l^{-1 }}$, ammonia $2.2 \mu \mathrm{mol} \mathrm{l^{-1 }}$, phosphate $0.78 \mu \mathrm{mol} \mathrm{l}^{-1}$, silicate $24.70 \mu \mathrm{mol} \mathrm{l} \mathrm{l}^{-1}$.

Eight mesocosms were established (duplicate mesocosms exposed to 4 temperature regimes in climate chambers). The initial temperature in the climate chamber with the 2 'baseline' mesocosms $\left(\Delta T 0^{\circ} \mathrm{C}\right.$ treatment) was adjusted to $2^{\circ} \mathrm{C}$, the normal in situ temperature during February. The temperature in this chamber was subsequently increased according to the decadal mean temperature of the winter/spring season in Kiel Fjord. The temperature of the other climate chambers was initially adjusted to 4,6 and $8^{\circ} \mathrm{C}$ and was subsequently run in parallel to the baseline; accordingly, mesocosms within the chambers were called $\Delta T+2^{\circ} \mathrm{C}, \Delta T+4^{\circ} \mathrm{C}$ and $\Delta T+6^{\circ} \mathrm{C}$, respectively. The initial temperature difference of $2^{\circ} \mathrm{C}$ between the different treatments was slowly reduced by $0.25^{\circ} \mathrm{C}$ $\mathrm{mo}^{-1}$, with the upper limit defined as the average summer temperature (Fig. 1) (Sommer et al. 2007). The temperature inside the chambers was computercontrolled; adjustments were made 4 times per day by temperature sensors calibrated with a WTW temperature sensor. Temperature regulation of the climate chambers was not efficient enough to keep the temperatures inside the mesocosms exactly at the planned levels (Fig. 1), but the intended temperature ranking between the treatments could be maintained through- 


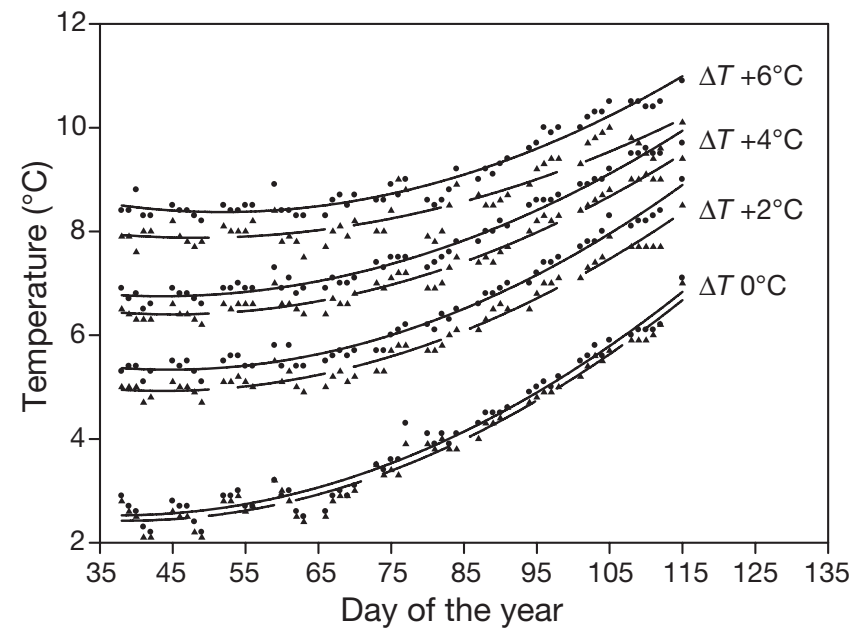

Fig. 1. Starting temperatures and temperature increases in 8 mesocosms during the spring experiment 2005 (2nd order polynomial regression lines). Light conditions were similar in all mesocosms

out the entire experiment. Therefore, the planned initial $\Delta T$ was used for the statistical analyses of biological responses to temperature.

The light regime was similar in all mesocosms and was adjusted to the mean light intensity $\left(I_{\text {mix }}\right)$ in a $12 \mathrm{~m}$ mixed water column (mixing depth of the fjord during the winter/spring season). This resulted in an $I_{\text {mix }}$ of $\sim 16 \%$ of the incident light $\left(I_{0}\right)$ according to the equation of Riley (1957):

$$
I_{\text {mix }}=I_{0}\left(1-\mathrm{e}^{-k z}\right)(k z)^{-1}
$$

where $k\left(0.5 \mathrm{~m}^{-1}\right)$ is the average light attenuation coefficient and $z$ the depth of the halocline (Sommer et al. 2007). Day length, daily light curve and cloudiness were controlled by a computer program according to meteorological data from the region.

Sampling. Samples for chemical and biological measurements were taken at least 3 times per week, during the blooming period even daily. Samples from the mesocosms were taken at 09:00 $\mathrm{h}$ and treated immediately as described below.

Chlorophyll and primary production. Chlorophyll was measured as the in vivo fluorescence of phytoplankton (proxy variable for chlorophyll, Beutler et al. 2002), using a Turner Fluorometer 10 AU (Turner Design).

Primary production (PP) was measured in samples incubated inside the mesocosms at medium depth. PP was calculated from $\left[{ }^{14} \mathrm{C}\right]$-bicarbonate $(4 \mu \mathrm{Ci}$ per $30 \mathrm{ml}$ bottle) uptake (Gargas 1975) under the in situ light conditions in the mesocosms for about $4 \mathrm{~h}$, with duplicate samples and 1 blank (dark). After incubation, the samples were filtered $(0.2 \mu \mathrm{m}$ polycarbonate filters), fumed with $\mathrm{HCl}$ and then radio-assayed (Packard
Tricarb counter, Lumagel scintillation cocktail). PP was calculated as $\mathrm{mg} \mathrm{C} \mathrm{m}^{-3} \mathrm{~d}^{-1}$, using the light curve from sunrise until sunset.

Counts of bacteria and nanoflagellates. Samples for bacterial counts (total bacterial number, TBN) were fixed with $2 \%$ (final concentration) formalin and counted after staining with DAPI (4,6-diamidino-2phenylindole, final concentration $100 \mu \mathrm{g} \mathrm{m} \mathrm{m}^{-1}$ ) in a Zeiss Axioplan epifluorescence microscope (Porter \& Feig 1980) at $1000 \times$ magnification.

Heterotrophic nanoflagellates (HNF) were stained with DAPI (final concentration $100 \mu \mathrm{g} \mathrm{ml}^{-1}$ ) and their numbers determined microscopically with an epifluorescence microscope.

Bacterial growth. Bacterial growth in terms of BSP was assessed by $\left[{ }^{3} \mathrm{H}\right]$ methyl-thymidine incorporation (TTi, DNA synthesis, Fuhrman \& Azam 1982). A final saturating concentration of $5.8 \mathrm{nM}\left[{ }^{3} \mathrm{H}\right]$ methyl-thymidine (specific activity $67 \mathrm{Ci} \mathrm{mmol}^{-1}$, Amersham) was added to $20 \mathrm{ml}$ samples (triplicates and 1 blank), which were then incubated in the dark for 2 to $4 \mathrm{~h}$ at in situ temperatures (in the climate chambers). Incubation was terminated by the addition of $1 \%$ formalin. The bacteria were collected on $0.2 \mu \mathrm{m}$ polycarbonate filters (Poretics) and rinsed 10 times with $1 \mathrm{ml}$ ice-cold $5 \%$ trichloroacetic acid. Samples were radio-assayed in a Packard Tricarb counter with Lumagel as the scintillation cocktail. A conventional conversion factor $\left(13.75 \mathrm{~kg} \mathrm{C} \mathrm{mol}^{-1}\right.$ thymidine, Fuhrman \& Azam 1982) was used to calculate bacterial C-production from thymidine incorporation. Bacterial growth was

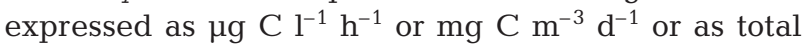
bacterial growth, integrating all the data over the entire experimental period or during the defined periods.

Respiration. Total community respiration and the respiration of organisms $<3 \mu \mathrm{m}$ were determined using the Winkler method (100 ml Winkler bottles, 3 parallel samples for the initial and for the final $\mathrm{O}_{2}$ measurements), modified by photometrical end-point determination of the titration. Incubation in the dark at the in situ temperature lasted $48 \mathrm{~h}$. Respiration was measured as $\mathrm{O}_{2}$ uptake $\left(\mathrm{mg} \mathrm{l}^{-1} \mathrm{~d}^{-1}\right)$ from the decrease of $\mathrm{O}_{2}$ concentration during the incubation period. This value was multiplied by a recommended factor of 0.32 (Gocke \& Hoppe 1977) in order to express C-utilisation for respiration as $\mathrm{mg} \mathrm{C} \mathrm{m} \mathrm{m}^{-3} \mathrm{~d}^{-1}$.

Data analysis. The data sets were statistically analysed using Sigma-stat analytical tools (test of normal distribution, Kolmogorov-Smirnov test), the least square fit method, and Mann-Whitney rank sum test. The timing of the peaks of maximal bacterial production and of the phytoplankton spring bloom in relation to temperature was computed from the regression between the days when these peaks occurred and the temperatures of the respective mesocosms $\left(\Delta T{ }^{\circ} \mathrm{C}\right)$. Several outliers were omitted if technical problems 
Table 1. Mean $( \pm \mathrm{SD}, \mathrm{n}=49)$ values of total bacterial numbers $\left(\mathrm{TBN} \times 10^{6} \mathrm{ml}^{-1}\right)$ in 8 mesocosms $(2$ at each temperature) and in the Kiel Fjord over the experimental period

\begin{tabular}{|c|c|c|c|c|c|}
\hline \multirow[b]{3}{*}{ TBN } & \multicolumn{4}{|c|}{ - Mesocosm treatment } & \multirow{3}{*}{$\begin{array}{c}\begin{array}{c}\text { In situ } \\
\text { Kiel Fjord }\end{array} \\
2.47 \pm 0.94\end{array}$} \\
\hline & $\Delta T 0^{\circ} \mathrm{C}$ & $\Delta T+2^{\circ} \mathrm{C}$ & $\Delta T+4^{\circ} \mathrm{C}$ & $\Delta T+6^{\circ} \mathrm{C}$ & \\
\hline & $1.66 \pm 0.41 \quad 1.66 \pm 0.57$ & $1.72 \pm 0.56 \quad 1.72 \pm 0.49$ & $1.61 \pm 0.37 \quad 1.83 \pm 0.59$ & $1.61 \pm 0.46 \quad 1.74 \pm 0.68$ & \\
\hline
\end{tabular}

were obviously involved. The time scale applied in this study is 'day of the year' because temperature, light and nutrient conditions in the baseline mesocosms were accurately adjusted to those in the Kiel Fjord during springtime.

\section{RESULTS}

\section{Chlorophyll and phytoplankton composition}

The timing of the chlorophyll maxima (measured by in situ fluorescence) during the spring bloom in the mesocosms was not significantly influenced by temperature. Peaks of chlorophyll occurred between day of the year (DOY) 87 and 89, ca. $50 \mathrm{~d}$ after the start of the experiment. Highest fluorescence was measured in the cold mesocosms, with decreasing fluorescence in the increasingly warmer ones (cf. Aberle et al. 2007, Sommer et al. 2007).

The patterns of chlorophyll (fluorescence) were accompanied by changes in the taxonomic composition of phytoplankton in the mesocosms (Sommer et al. 2007). The phytoplankton composition started to diverge already during the phase before the bloom. In the coldest mesocosms, diatoms (mainly Chaetoceros curvisetus and Probosica alata) predominated. Together, these 2 species comprised 45 to $70 \%$ of the total algal biomass. Nanoflagellates, mainly represented by Chrysochromolina (12 to $23 \%$ ), were also present. In contrast, in the warmest mesocosms, diatoms were insignificant whereas flagellates of the species Plagioselmis prolonga, Teleaulax acuta and Chrysochromulina sp. dominated the phytoplankton biomass (46 to $56 \%$ ) during the spring bloom. During the postbloom phase, these trends were no longer apparent, replaced by a unimodal response of pico-phytoplankton to temperature.

\section{Bacterial abundance and heterotrophic nanoflagellates}

The average values of bacterial counts per ml (TBN) over the experimental period were similar for all mesocosms and the variability (SD) was relatively low
(Table 1). However, the counts differed significantly from the considerably higher values obtained from the reference station in Kiel Fjord (Table 1). HNF developed strongly (up to 911 ind. $\mathrm{ml}^{-1}$ ) during the prebloom phase, particularly in the warmest mesocosms, while their numbers remained lower (684 ind. $\mathrm{ml}^{-1}$ ) in the coldest mesocosms (data not shown). During the bloom, HNF were present in relatively low numbers in the warmest mesocosms (417 ind. $\mathrm{ml}^{-1}$ ) but increased in abundance in the post-bloom phase (up to 1350 ind. $\mathrm{ml}^{-1}$ ). In contrast, the concentration of HNF increased to 1800 ind. $\mathrm{ml}^{-1}$ during the bloom in the coldest mesocosms and decreased thereafter.

\section{Primary production}

Although the mesocosms were initially well supplied with nutrients from the Kiel Fjord winter water, PP started at a very low level in all mesocosms (Fig. 2). Soon after the start of the experiment, there was a slight decrease in $\mathrm{PP}$, which was more pronounced in the warm mesocosms. A similar decrease was observed for the other microbial variables and may have indicated a period of re-conditioning after the turbulence caused by filling of the mesocosms. During DOY 68 to 74 , PP escalated and peaked a few days later. Due to the development of diatoms, the highest peaks of the phytoplankton bloom were recorded in the cold baseline mesocosms $\left(\Delta T 0^{\circ} \mathrm{C}\right)$, while peaks were lower in the warmer mesocosms, in which nanoplankton were dominant. After the spring bloom, PP declined rapidly. This decrease was steeper in the cold than in the warm mesocosms (Fig. 2). Linear regression analysis revealed that the timing of the peaks of PP did not depend on the incubation temperature of the mesocosms (not significant at the $\mathrm{p}<0.05$ level) as expected in a low-light regime. On average, the parallel mesocosms peaked at DOY 89, 87,83 and 85 in the mesocosms started at $\Delta T=0,2,4$ and $6^{\circ} \mathrm{C}$, respectively.

In contrast to the timing of the spring bloom peak, there was a pronounced and statistically significant (negative) correlation between PP and temperature when the integrated values of $\mathrm{PP}\left(\mathrm{PP}_{\text {int }}\right)$ from the different mesocosms were compared: 


$$
\begin{gathered}
\mathrm{PP}_{\text {int }}=511-42.6 \Delta T \\
\mathrm{r}^{2}=0.68 ; \mathrm{p}=0.012
\end{gathered}
$$

In this equation, $\mathrm{PP}_{\text {int }}$ is the integrated $\mathrm{PP}$ over the phytoplankton bloom from DOY 68 to 76 (start of the bloom in the different mesocosms) to DOY 110 (end of the PP measurements) at a given $\Delta T$ compared to the baseline treatment $\Delta T 0^{\circ} \mathrm{C}$ (in $\mathrm{mg} \mathrm{C} \mathrm{m}^{-3}$, derived from the geometric means of PP between sampling dates).

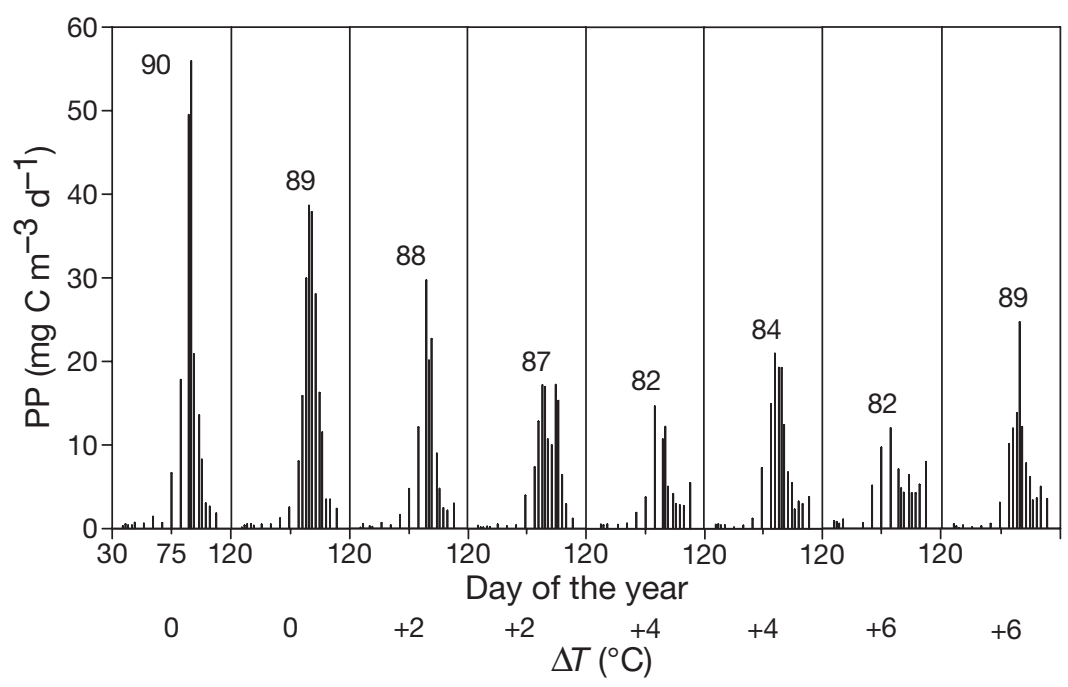

Fig. 2. Time course of primary production (PP) in the 8 mesocosms. Temperatures of the mesocosms $(\Delta T)$ are listed below the time scale. Days when maximal PP was recorded (spring bloom) are indicated above the respective column

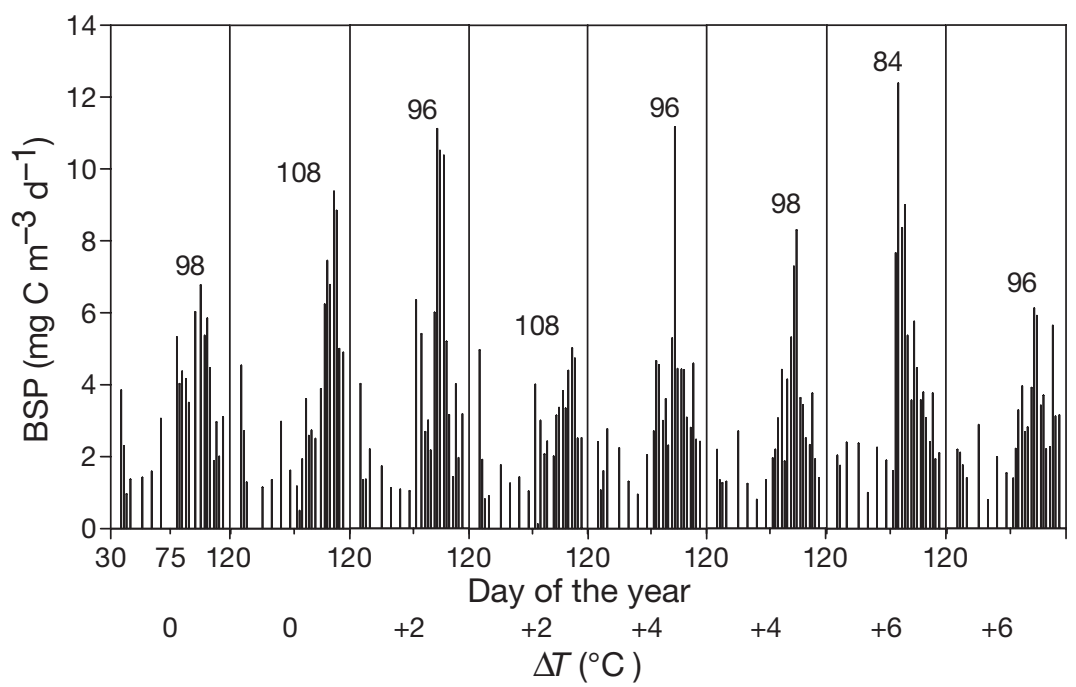

Fig. 3. Time course of bacterial secondary production (BSP) in the 8 mesocosms. Temperatures of the mesocosms $(\Delta T)$ are listed below the time scale. Days when maximal BSP was measured are indicated. Timing of maximal BSP ( $t_{\text {maxBSP}}$, day of the year) is presented in Eq. (3) (see 'Results; Bacterial secondary production')

\section{Bacterial secondary production}

The patterns of BSP for the different treatments during the experimental period are shown in Fig. 3. BSP started at a relatively high rate, probably benefiting from the initial turbulence and quite high DOC (dissolved organic carbon, cf. 'Discussion') in the mesocosms. Thereafter, BSP decreased for several days until the peak of degradation occurred. In contrast to $\mathrm{PP}$, the rates of BSP remained relatively high in the post-bloom phase.

The timing of peak BSP with respect to temperature is important for assessing the time lag between the peaks of the phytoplankton bloom and of bacterial degradation of organic matter derived from phytoplankton. Bacterial production peaked between DOY 84 and 108. On average, the parallel mesocosms peaked at DOY 103, 102, 97 and 90 in the mesocosms $\Delta T 0, \Delta T+2, \Delta T+4$ and $\Delta T$ $+6^{\circ} \mathrm{C}$, respectively. However, there was considerable variation between the parallel mesocosms. A comparison of the timings of peak PP and BSP (derived from averages of parallel mesocosms) showed that the difference between them accounted for about $14 \mathrm{~d}$ in the mesocosms $\Delta T \quad 0, \Delta T+2$ and $\Delta T+4^{\circ} \mathrm{C}$, but only $5 \mathrm{~d}$ in $\Delta T+6^{\circ} \mathrm{C}$.

However, in contrast to the timing of peak PP, which did not correlate with temperature, the peaks of BSP were closely related to temperature, as shown by:

$$
\begin{gathered}
t_{\operatorname{maxBSP}}=105-2 \Delta T \\
\text { regression: } \mathrm{p}=0.044 ; \text { constant: } \\
\mathrm{p}<0.001
\end{gathered}
$$

where $t_{\text {maxBSP }}$ is the time of the maximum of BSP (DOY) and $\Delta T$ the difference in the temperature between a given mesocosm and the baseline treatment $\Delta T 0^{\circ} \mathrm{C}$. With respect to the predicted warming during winter/early spring, application of Eq. (2) suggests that bacterial degradation (BSP) would reach its peak about $2 \mathrm{~d}$ earlier in the year per ${ }^{\circ} \mathrm{C}$ of temperature increase, compared to the recent conditions. If the timing of peak PP is not affected by an increase in temperature, as suggested by our experiments, the indicated thermal acceleration of BSP would be expected to reduce also the lag time between PP and BSP (C-fixation and C-mineralisation). For example, in 
the mesocosms $\Delta T 0^{\circ} \mathrm{C}$ PP peaked at DOY 89 while BSP peaked at DOY 105 (as determined from Eq. 2). Acceleration of BSP by (theoretically) $2 \mathrm{~d}$ per ${ }^{\circ} \mathrm{C}$ would reduce the corresponding lag time of $16 \mathrm{~d}$ to $4 \mathrm{~d}$ in the warm mesocosms $\Delta T+6^{\circ} \mathrm{C}$ ).

In contrast to integrated PP (Eq. 1), integrated BSP $\left(\mathrm{BSP}_{\text {int }}\right.$, Table 2$)$ was not significantly related to temperature. $\mathrm{BSP}_{\text {int }}$ over the experimental period remained fairly constant and obviously did not react to changes in temperature and PP occurring in the mesocosms (Table 2).

\section{Ratio between primary production and bacterial secondary production}

An aim of the present study was to assess the temperature dependency of the trophic status (PP:BSP ratio). Eq. 3 is based on the production values (PP and BSP), expressed as mg C m $\mathrm{m}^{-3} \mathrm{~d}^{-1}$ and integrated over the experimental period (Fig. 4):

$$
\begin{gathered}
\text { BSP:PP }(\%)=39.7+4.2 \Delta T \\
r^{2}=0.6 ; p=0.024
\end{gathered}
$$

BSP:PP increased continuously, from $40 \%$ at $\Delta T=$ $0^{\circ} \mathrm{C}$ up to $63 \%$ in the mesocosms started at $\Delta T=+6^{\circ} \mathrm{C}$ (Fig. 4). This means that at elevated temperatures a relatively higher percentage of PP (proxy for bacterial substrate availability) was utilised by bacteria than at low temperature, thus shifting the trophic status of the system towards heterotrophic. In detail (Table 3), BSP exceeded PP before the start of the spring bloom, but the absolute values of both variables were low, particularly those of PP. During the bloom, BSP was relatively low in relation to PP, especially in the cold mesocosms (Table 3, Fig. 5). Soon after the bloom, BSP increased again and approached or exceeded PP, particularly in the cold mesocosms.

Table 2. Primary production (PP) and bacterial secondary production (BSP) rates (mean $\pm \mathrm{SD} ; \mathrm{mg} \mathrm{C} \mathrm{m}^{-3} \mathrm{~d}^{-1}$ ) and total PP and total BSP integrated over the experimental period ( $\mathrm{mg} \mathrm{C} \mathrm{m}{ }^{-3}$; mean in parentheses) in 8 mesocosms

\begin{tabular}{|c|c|c|c|c|c|c|c|c|}
\hline \multirow[b]{3}{*}{ PP } & \multirow{2}{*}{\multicolumn{2}{|c|}{$\Delta T 0^{\circ} \mathrm{C}$}} & \multirow{2}{*}{\multicolumn{2}{|c|}{$\begin{array}{l}\text { Mesocos } \\
\Delta T+2^{\circ} \mathrm{C}\end{array}$}} & reatme & & & \\
\hline & & & & & \multicolumn{2}{|c|}{$\Delta T+4^{\circ} \mathrm{C}$} & \multicolumn{2}{|c|}{$\Delta T+6^{\circ} \mathrm{C}$} \\
\hline & $\begin{array}{c}9.0 \\
\pm 13.6\end{array}$ & $\begin{array}{c}7.7 \\
\pm 11.1\end{array}$ & $\begin{array}{c}5.9 \\
\pm 7.8\end{array}$ & $\begin{array}{c}5.0 \\
\pm 5.7\end{array}$ & $\begin{array}{c}4.2 \\
\pm 4.2\end{array}$ & $\begin{array}{c}5.5 \\
\pm 6.4\end{array}$ & $\begin{array}{c}4.8 \\
\pm 3.6\end{array}$ & $\begin{array}{c}4.5 \\
\pm 5.3\end{array}$ \\
\hline Total PP & \multicolumn{2}{|c|}{$(602)$} & \multicolumn{2}{|c|}{ (394) } & \multicolumn{2}{|c|}{ (337) } & \multicolumn{2}{|c|}{ (334) } \\
\hline BSP & $\begin{array}{c}3.4 \\
\pm 1.7\end{array}$ & $\begin{array}{c}2.9 \\
\pm 2.2\end{array}$ & $\begin{array}{c}3.3 \\
\pm 2.8\end{array}$ & $\begin{array}{c}2.2 \\
\pm 1.2\end{array}$ & $\begin{array}{c}2.9 \\
\pm 1.8\end{array}$ & $\begin{array}{c}2.6 \\
\pm 1.7\end{array}$ & $\begin{array}{c}3.3 \\
\pm 2.1\end{array}$ & $\begin{array}{c}2.6 \\
\pm 1.2\end{array}$ \\
\hline Total BSP & 245 & $28)$ & 240 & $\begin{array}{l}161 \\
00)\end{array}$ & 204 & $\begin{array}{l}184 \\
94)\end{array}$ & $\begin{array}{r}234 \\
(2\end{array}$ & 182 \\
\hline
\end{tabular}
( 2 at each temperature)

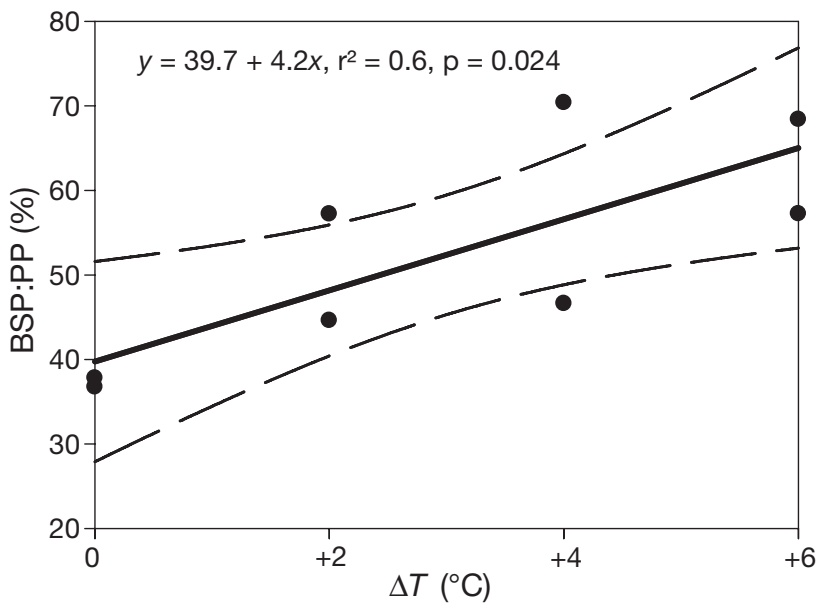

Fig. 4. Ratio of bacterial secondary production to primary production (BSP:PP) in relation to the $\Delta T$ of the treatments. PP and BSP were calculated in terms of $\mathrm{mg} \mathrm{C} \mathrm{m} \mathrm{C}^{-3} \mathrm{~d}^{-1}$ and integrated over the experimental period. Regression line and $95 \%$ confidence intervals are shown

\section{Respiration, bacterial growth efficiency and bacterial carbon demand}

The mean values of community respiration increased about 2.5 times along the tested temperature gradient. The contribution of the $<3 \mu \mathrm{m}$ size fraction, consisting mainly of bacteria and flagellates (bacterial respiration, BR), to community respiration increased considerably at elevated temperatures (Fig. 6). In detail, the contributions of BR to community respiration over the experimental period were 59,67, 74 and 77, averages of the parallel mesocosms $\Delta T 0, \Delta T+2, \Delta T+4$ and $\Delta T+6^{\circ} \mathrm{C}$, respectively. Added mesozooplankton died within a short period, particularly in the warm mesocosms, and did not contribute significantly to total respiration (but to substrate supply). In any case, BR exceeded BSP several times (Fig. 5). Bacterial growth efficiency (BGE, the percentage of total organic matter uptake used for bacterial biomass production) decreased from ca. $21 \%$ in the cold mesocosms to $13 \%$ in the warm ones (calculated from data in Fig. 5).

The ratio between bacterial carbon demand (BCD, bacterial C-incorporation plus C-respiration) and $\mathrm{PP}$, which is an important variable for evaluating changes in the marine $\mathrm{C}$-cycle, was also influenced by temperature. Commonly, it is expected that the autochthonously produced organic matter (PP, particularly in offshore regions) is sufficient to supply the $\mathrm{C}$ demands for growth and 

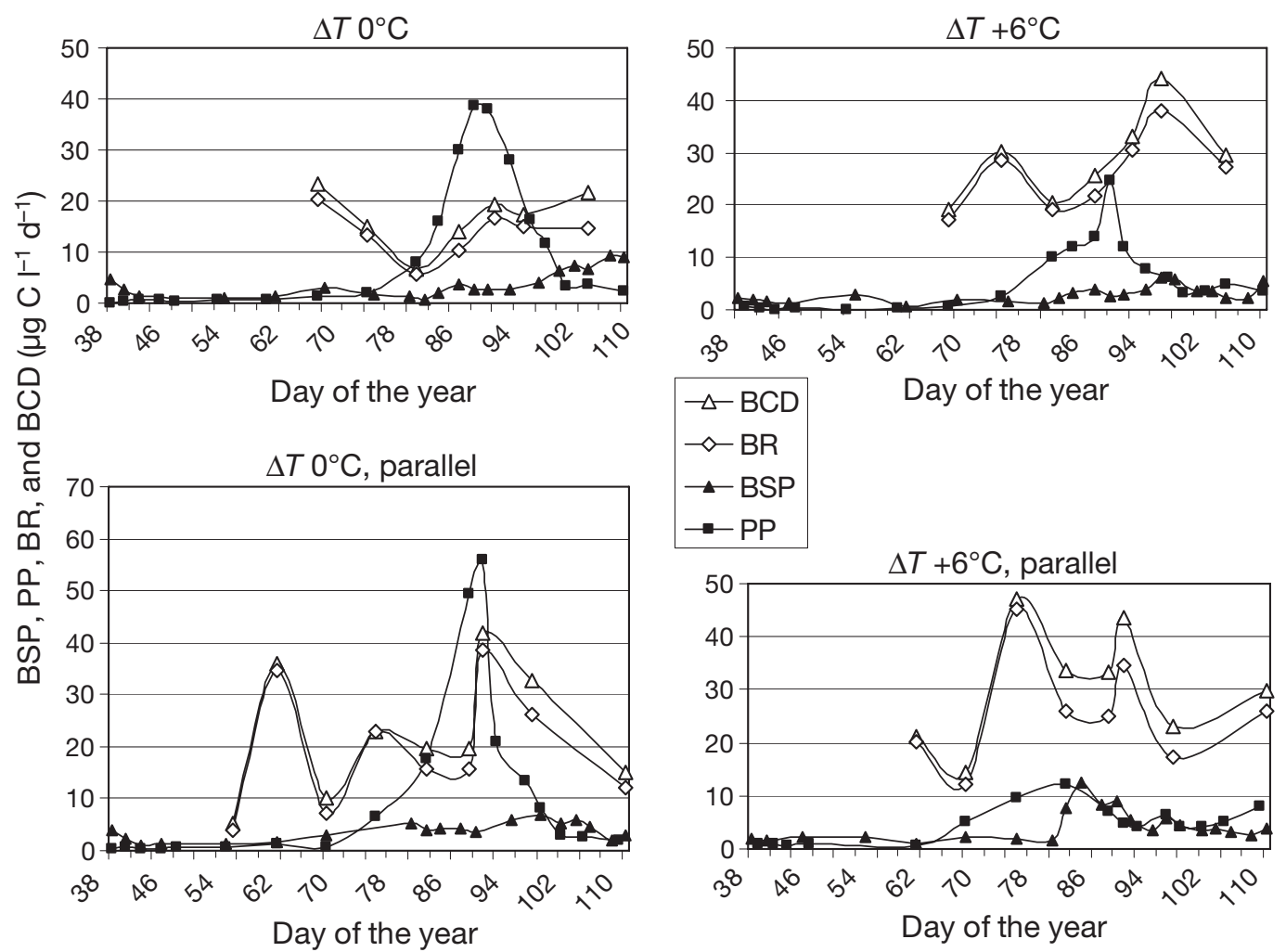

Fig. 5. Time courses of bacterial secondary production (BSP), primary production (PP), bacterial respiration (BR; particle size class $<3 \mu \mathrm{m}$, bacteria and other microheterotrophs) and bacterial carbon demand (BCD, the sum of BSP and BR) in the 2 coldest mesocosms compared to the 2 warmest ones

respiration of bacteria and the rest of the heterotrophic community. In our experiments, in which inshore water with additional allochthonous organic matter was used, the PP measured in the warm $(\Delta T$

Table 3. Ratios (\%) between bacterial secondary production (BSP) and primary production (PP) during different phases of the spring bloom. SDs of the parallel mesocosms in parentheses

\begin{tabular}{|lcc|}
\hline & Mesocosm treatment & BSP:PP \\
\hline Total incubation period & $\Delta T 0^{\circ} \mathrm{C}$ & $37(1)$ \\
& $\Delta T+2^{\circ} \mathrm{C}$ & $51(9)$ \\
& $\Delta T+4^{\circ} \mathrm{C}$ & $58(17)$ \\
Before bloom & $\Delta T+6^{\circ} \mathrm{C}$ & $63(8)$ \\
& $\Delta T 0^{\circ} \mathrm{C}$ & $191(10)$ \\
& $\Delta T+2^{\circ} \mathrm{C}$ & $166(17)$ \\
& $\Delta T+4^{\circ} \mathrm{C}$ & $169(24)$ \\
During bloom & $\Delta T+6^{\circ} \mathrm{C}$ & $209(76)$ \\
& $\Delta T 0^{\circ} \mathrm{C}$ & $19(6)$ \\
& $\Delta T+2^{\circ} \mathrm{C}$ & $29(7)$ \\
After bloom & $\Delta T+4^{\circ} \mathrm{C}$ & $35(10)$ \\
& $\Delta T+6^{\circ} \mathrm{C}$ & $44(19)$ \\
& $\Delta T 0^{\circ} \mathrm{C}$ & $215(68)$ \\
$\Delta T+2^{\circ} \mathrm{C}$ & $216(19)$ \\
$\Delta T+4^{\circ} \mathrm{C}$ & $115(5)$ \\
& $\Delta T+6^{\circ} \mathrm{C}$ & $72(19)$ \\
\hline
\end{tabular}

$+6^{\circ} \mathrm{C}$ ) mesocosms covered only 22 to $26 \%$ of the $\mathrm{BCD}$, whereas in the cold mesocosms $\left(\Delta T 0^{\circ} \mathrm{C}\right), \mathrm{PP}$ and $\mathrm{BCD}$ were more balanced (84 to $95 \%$, based on the data in Fig. 5).

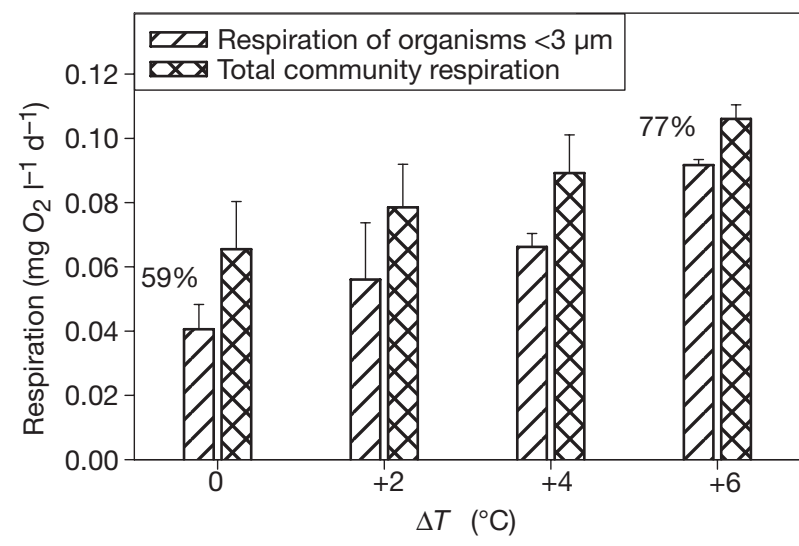

Fig. 6. Average values of total respiration compared to respiration measured in organisms comprising the particle size class $<3 \mu \mathrm{m}$ (bacteria and other microheterotrophs) in the different bacterial secondary production treatments. Columns show mean values of 7 to 8 measurements distributed over nearly the entire experimental period. Error bars are $+\mathrm{SD}$ between parallel mesocosms 


\section{DISCUSSION}

Organic matter fluxes and nutrient recycling in the sea are controlled by microbes (Azam 1998) and strongly affect global climate (Rivkin \& Legendre 2001). However, predictions of the biotic responses to climate change may be misleading if changes in the interaction of species are ignored (Davis et al. 1998). This holds true for the interactions between food web components or trophic levels and their response to climate variability. In the present study, we focused on changes in the interaction (coupling) between phototrophic and heterotrophic microbes in order to try to understand 'the scales over which climate will change and living systems will respond' (Harley et al. 2006, p. 228). To approach this problem, in addition to carrying out field investigations, ecosystem experiments are required, which lead to 'conclusive tests of key hypotheses and paradigms' as suggested by Duarte et al. (1997, p. 101).

Results of field studies in the Baltic Sea and in other seas of the temperate climate belt suggest that low springtime temperatures may cause a delay in the bacterial degradation of organic matter produced by phytoplankton during the spring bloom (e.g. Blight et al. 1995, Jost \& Pollehne 1998). However, information on the extent of this delay is scarce and investigations with regard to the predicted scenario of global warming are missing. In the present study, we have tried to fill this gap by more accurately specifying this period of bacterial enhancement (or retardation). Our experiments were carried out in temperature-controlled indoor mesocosms filled with winter water from Kiel Fjord. The initial temperature range of 2 to $8^{\circ} \mathrm{C}$ (approaching 6 to $11^{\circ} \mathrm{C}$, respectively, after $75 \mathrm{~d}$ incubation, Fig. 1) was realistic in consideration of the predicted climate change scenarios; nevertheless, it was relatively narrow with respect to the reactivity of thermotolerant biological processes. Thus, it could not be expected that the responses of flexible microbial populations within the applied temperature range would be very strong and easily measurable by the available methods.

\section{Temporal succession patterns of phytoplankton and bacteria}

Changes in the temporal coupling between phytoplankton and bacteria, analysed through simultaneous investigation of the individual components, have rarely been reported (Pomeroy \& Deibel 1986, Blight et al. 1995, Pomeroy \& Wiebe 2001). In our experiments, the timing of the maxima of PP (spring bloom) and BSP differed in response to changes in temperature. While the timing of maximal PP was not significantly affected by an increase in temperature, a pronounced trend was observed concerning the thermal acceleration of peak BSP from DOY 103 to 90 (average of the parallel mesocosms, Fig. 3). This implies that coupling between the phytoplankton spring bloom and bacterial degradation was probably tighter at elevated temperatures because the time lag between production and degradation of organic matter diminished. Specifically, peak BSP occurred 16 d later than peak PP in the cold mesocosms $\left(\Delta T 0^{\circ} \mathrm{C}\right)$, and this time lag was reduced to ca. $4 \mathrm{~d}$ in the warmest mesocosms $\left(\Delta T+6^{\circ} \mathrm{C}\right)$. Our observations correspond surprisingly well to the 1 to $2 \mathrm{wk}$ time lag between the peaks of spring bloom and community respiration (dominated by bacteria) reported by Blight et al. (1995) in their study of 3 seasonal cycles in the Menai strait (Irish Sea). Remarkably, the geographical latitude of the strait is similar to that of Kiel Fjord, which implies that the temperature regimes were comparable.

\section{Quantitative relationships between primary production and bacterial secondary production}

As a consequence of the different responses of phytoplankton and heterotrophic bacteria to increases in temperature, the temporal coupling between these trophic levels changed. This was accompanied by changes in the ratio of BSP to phytoplankton PP (BSP:PP), which increased from 37 to $63 \%$ along the temperature gradient between the mesocosms (derived from the regression line shown in Fig. 4). These values were rather high compared to the ratios reported from similar temperature gradients in natural environments, e.g. 12 to $22 \%$ in gradients of the Southern Atlantic (Lochte et al. 1997), and the even lower ratios determined by Hoppe et al. (2002) along a meridional Atlantic transect. Very low values of the ratio (1 to $10 \%$ ), accompanied by a weak coupling between PP and BSP, were measured by Duarte et al. (2005), who studied in situ mesocosms filled with cold Antarctic water. In contrast, our ratios are close to those reported by Li et al. (1993) in their investigation of the spring bloom in the western North Atlantic (16 to $36 \%)$. The relatively high ratios determined in the present study were probably due to carbon partitioning between POC (particulate organic carbon) production and DOC, which strongly favoured the latter, as observed by Søndergaard et al. (2000) in their mesocosm experiments. It should be noted that the increase in the ratio measured in our warmer mesocosms was mainly caused by a reduction in PP (relative to the cold mesocosms), which was probably supported by changes in phytoplankton species composition (see 
'Results; Chlorophyll and phytoplankton composition'). Thus, we derive from our results that, as it may be combined with climate warming, a higher BSP:PP ratio (and a closer temporal coupling between PP and BSP) will not necessarily lead to an increase in the amount of recycled products, if the source of organic matter (PP) is negatively affected.

\section{Responses of respiration, bacterial growth efficiency and bacterial carbon demand to warming}

Community (total) respiration increased at elevated temperatures as did the contribution of bacteria and other microheterotrophs (particle size fraction $<3 \mu \mathrm{m}$ ) to total respiration (Fig. 6). Since the substrate supply was similar and sufficient (DOC varied over the experimental period between 100 and $215 \mu \mathrm{mol} \mathrm{l}^{-1}$; J. Wohlers unpubl.) in each of the mesocosms, we conclude that temperature must have been mainly responsible for the increased respiration in the warm mesocosms. In contrast, Lopez-Urrutia \& Moran (2007) suggested that, in warm oligotrophic waters, strong resource limitation of bacterial growth but not temperature may stimulate respiration. Thus, temperature may regulate microbial respiration by 2 different means: If substrate supply is sufficient (as in our experiments), temperature seems to be the principal regulator, whereas, if substrate is scarce, temperature may no longer be as important.

In contrast to respiration, BGE decreased from roughly $21 \%$ in the cold mesocosms to $13 \%$ in the warm ones (calculated from data shown in Fig. 5). This is at the lower end of BGE ranges observed in different aquatic regions, derived from data collected during ocean-wide cruises (del Giorgio et al. 1997, Duarte \& Agusti 1998, Middelboe \& Søndergaard 1993, Rivkin \& Legendre 2001). Nevertheless, in general, our results are consistent with the observation of decreasing BGE values at elevated temperatures in surface waters.

BCD exceeded PP, particularly during the pre-bloom phase (as also observed by Kankaala et al. 1996, and by Williams et al. 2004 at an oligotrophic ocean site) but decreased to relatively low values shortly before the bloom peaked (Fig. 5). The fact that the degradation of organic matter surpassed PP during the prebloom phase may have been partly due to the organic matter load present in the winter water transferred to the mesocosms. Initial concentrations of DOC in the mesocosms were relatively high (ca. $180 \mu \mathrm{mol} \mathrm{l}^{-1}$ ), but

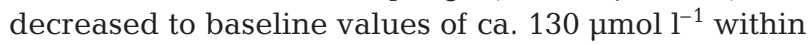
a few days (J. Wohlers unpubl.). Another source was probably dying mesozooplankton, added to the mesocosms at the beginning of the experiments, which supported BCD in addition to autochthonous PP. Further, Williams et al. (2004) attributed such phenomena of C over-consumption to differences in the dynamics of photosynthesis (more dynamic) and respiration (less dynamic), which may (theoretically) lead to discrepancies between these 2 variables (if integrated over a longer period) in the case of under-sampling. Finally, the observed mismatch between PP and BCD can possibly be attributed to faster recycling and re-utilisation of $\mathrm{C}$ by the microbial food web and to wall growth of algae (which was not considered in our PP measurements), particularly in the warm mesocosms.

During the spring bloom, PP surpassed BCD for growth (Table 3, Fig. 5) and there was a clear trend along the temperature gradient from cold to warm mesocosms. This trend was reversed during the postbloom phase, dominated by bacterial degradation. Thus, it seems that the relatively low level of degradation in the cold mesocosms during the bloom was balanced by elevated degradation during the postbloom phase. Conversely, in the warm mesocosms, much of the organic matter produced during the spring bloom was immediately degraded by bacteria such that less remained for subsequent bacterial degradation in the post-bloom phase.

The observed increases in bacterial conversion of organic matter (PP) together with enhanced respiration (lower BGE) suggest faster bacterial C-mineralisation at elevated temperatures, which ultimately may affect the $\mathrm{CO}_{2}$ exchange between water and the atmosphere. However, the question remains whether this effect can be reduced or even eliminated by decreasing PP possibly in combination with warming.

\section{Other regulating factors and perspectives}

While the effect of an increase in temperature on microbial communities during winter/spring was the focus of this study, the roles of other regulating factors, such as grazing (Zubkov et al 2000), organic matter supply (Pomeroy et al. 1991), light conditions and viral infection, on the observed temperature response cannot be ignored. Flagellates were particularly abundant during the initial period in the warm mesocosms, while in the cold mesocosms they developed strongly during the spring bloom (cf. 'Results'). These patterns of HNF abundance were likely responsible for the relatively low numbers of bacteria (not shown) in the cold mesocosms during the bloom, but there were obviously no effects on BSP. In all other cases, negative correlations between HNF and bacteria were not observed, probably due to the control of HNF by their grazers (e.g. ciliates). Strong effects of a viral infection can probably be excluded because no 'catastrophes' occurred with respect to bacterial numbers and bacterial production during the experiment. 
Middelboe \& Lundsgaard (2003) investigated the relative effect of both substrate supply and temperature on microbial activities in natural environments and emphasised the dominance of organic substrate over temperature. The same holds true concerning inorganic nutrient availability (Christoffersen et al. 2006). In our experiments, substrate and nutrient supplies were similar (at least initially) and constantly high (cf. 'Results') in all mesocosms. Thus, we attribute the results mainly to the influence of temperature on the measured microbial variables.

Another interesting aspect involves the ratios of variables related to particulate organic matter (POM) (data not shown, cf. Sommer et al 2007) during the final degradation phase (dominated by bacteria). C:N ratios of POM remained fairly constant over the total experiment (ca. 8), whereas C:P and N:P ratios increased considerably during the final phase (from about 130 to 250 and 18 to 30 , respectively; J. Wohlers unpubl.), probably indicating $\mathrm{P}$ deficiency in the degrading bacterial community. However, there seemed to be no pronounced effects of temperature on these ratios.

Reliable predictions of the effects of climate warming on light intensity are not available. Light intensity was very low at the beginning of our experiment ( $16 \%$ of incident light, partly due to the high degree of simulated cloud cover). These conditions caused a long lag phase preceding the start of the spring bloom, during which the surfaces of the mesocosms were increasingly colonised by algae. Thus, we confine the validity of our results to shallow coastal regions where the sessile benthic microflora participates (e.g. by removing nutrients for photosynthesis from the water) in the regulation of pelagic relationships between PP and BSP.

One experiment is certainly not sufficient to draw firm conclusions. In some cases, the development of organisms and activities in parallel mesocosms varied considerably, even though the water quality in the mesocosms was initially exactly the same. Nevertheless, the present study has shown that it is possible to reproduce the typical pattern of in situ succession, i.e. a spring bloom of phytoplankton (Sommer et al. 1986, 2007) followed by a period of enhanced bacterial degradation of organic matter. It was also possible to define the lag time between the spring bloom and the peak of bacterial degradation, which is predicted to change in response to global warming. Although the temporal relationship between the peaks of PP and BSP was statistically not significant, it suggested a trend that might be elucidated in further investigations. We are convinced that mesocosm experiments of this type can provide relevant information on biological phenomena combined with climate change in terms of the predicted temperature increase.
Acknowledgements. We thank the DFG (German Research Foundation) for support of our project (Ju367/7-1) within the priority program 1162, AQUASHIFT. We thank T. Hansen for the maintenance of the mesocosms, M. Sando for light calculations and the biochemical AQUASHIFT group, particularly J. Wohlers, for providing us with data of inorganic nutrients and organic components (POC, PON, POP, DOC, DON).

\section{LITERATURE CITED}

Aberle N, Lengfellner K, Sommer U (2007) Spring bloom succession, grazing impact and herbivore selectivity of ciliate communities in response to winter warming. Oecologia 150:668-681

Azam F (1998) Microbial control of oceanic carbon flux: the plot thickens. Science 280:694-696

Beisner BE, McCauley E, Wrona FJ (1997) The influence of temperature and food chain length on plankton predator-prey dynamics. Can J Fish Aquat Sci 54:586-595

Berg GM, Glibert PM, Chen CC (1999) Dimension effects of enclosures on ecological processes in pelagic systems. Limnol Oceanogr 44:1331-1340

Beutler M, Wiltshire KH, Meyer B, Moldaenke C and others (2002) A fluorometric method for the differentiation of algal populations in vivo and in situ. Photosynth Res 72: $39-53$

Blight SP, Benthley TL, Lefevre D, Robinson C, Rodrigues R, Rowlands J, Williams PJleB (1995) Phasing of autotrophic and heterotrophic plankton metabolism in a temperate coastal ecosystem. Mar Ecol Prog Ser 128:61-75

Christoffersen K, Andersen N, Søndergaard M, Liboriussen L, Jeppesen E (2006) Implications of climate-enforced temperature increases on freshwater pico- and nanoplankton populations studied in artificial ponds during 16 months. Hydrobiologia 560:259-266

Cushing DH (1975) Marine ecology and fisheries. Cambridge University Press, Cambridge

> Davis AJ, Jenkinson LS, Lawton JH, Shorrocks B, Wood S (1998) Making mistakes when predicting shifts in species range in response to global warming. Nature 391: 783-786

del Giorgio PA, Cole JJ, Cimbleris A (1997) Respiration rates of bacteria exceed phytoplankton production in unproductive aquatic systems. Nature 385:148-151

> Duarte CM, Agusti S (1998) The $\mathrm{CO}_{2}$ balance of unproductive aquatic ecosystems. Science 281:234-236

> Duarte CM, Gasol M, Vaqué D (1997) Role of experimental approaches in marine microbial ecology. Aquat Microb Ecol 13:101-111

Duarte CM, Agusti S, Vaqué D, Agawin NSR, Felipe J, Casamayor EO, Gasol JM (2005) Experimental test of bacteria-phytoplankton coupling in the Southern Ocean. Limnol Oceanogr 50:1844-1854

Edwards M, Richardson AJ (2004) Impact of climate change on marine pelagic phenology and trophic mismatch. Nature 430.881-884

Fuhrman JA, Azam F (1982) Thymidine incorporation as a measure of heterotrophic bacterioplankton production in marine surface waters: evaluation and field results. Mar Biol 66:109-120

Gargas E (1975) A manual for phytoplankton primary production studies in the Baltic. The Baltic Marine Biologists No 2

Gocke K, Hoppe HG (1977) Determination of organic substances and respiration potential. In: Rheinheimer G (ed) Microbial ecology of a brackish water environment. Springer Verlag, Berlin, p 61-70 
Harley CDG, Hughes AR, Hultgreen KM, Miner BG and others (2006) The impact of climate change in coastal marine systems. Ecol Lett 9:228-241

Hoppe HG, Gocke K, Koppe R, Begler C (2002) Bacterial growth and primary production along a North-South Atlantic transect. Nature 416:168-171

IPCC (2001) Climate change 2001, Synthesis report. Third Assessment Report of the Intergovernmental Panel on Climate Change. Cambridge University Press, Cambridge

Jost G, Pollehne F (1998) Coupling of autotrophic and heterotrophic processes in a Baltic estuarine mixing gradient (Pomeranian Bight). Hydrobiologia 363:107-115

Kankaala P, Arvola L, Tulonen T, Ojala A (1996) Carbon budget for the pelagic food web of the euphotic zone in a boreal lake (Lake Paajarvi). Can J Fish Aquat Sci 53:1663-1674

Kirchman DL, Malmstrom RR, Cottrell NT (2005) Control of bacterial growth by temperature and organic matter in the Western Arctic. Deep-Sea Res II 52:3386-3395

Li WKW, Dickie PM, Harrison WG, Irwin BD (1993) Biomass and production of bacteria and phytoplankton during the spring bloom in the western North Atlantic Ocean. DeepSea Res II 40:307-327

Lochte K, Bjørnsen PK, Giesenhagen H, Weber A (1997) Bacterial standing stock and production and their relation to phytoplankton in the Southern Ocean. Deep-Sea Res II 44:321-340

Lopez-Urrutia A, Moran XAG (2007) Resource limitation of bacterial production distorts the temperature dependence of ocean carbon recycling. Ecology 88:817-822

Middelboe M, Lundsgaard C (2003) Microbial activity in the Greenland Sea: role of DOC lability, mineral nutrients and temperature. Aquat Microb Ecol 32:151-163

Middelboe M, Søndergaard M (1993) Bacterioplankton growth yield-seasonal variations and coupling to substrate lability and beta-glucosidase activity. Appl Environ Microbiol 59:3916-3921

Muren U, Samuelsson K, Andersson A (2005) Potential effects of elevated sea-water temperature on pelagic food webs. Hydrobiologia 545:153-165

Editorial responsibility: Fereidoun Rassoulzadegan, Villefranche-sur-Mer, France
Pomeroy LR, Deibel D (1986) Temperature regulation of bacterial activity during the spring bloom in Newfoundland coastal waters. Science 233:359-361

Pomeroy LR, Wiebe WJ (2001) Temperature and substrates as interactive limiting factors for marine heterotrophic bacteria. Aquat Microb Ecol 23:187-204

Pomeroy LR, Wiebe WJ, Deibel D, Thompson RJ, Rowe GT, Pakulski JD (1991) Bacterial responses to temperature and substrate concentration during the Newfoundland spring bloom. Mar Ecol Prog Ser 75:143-159

Porter KG, Feig YS (1980) The use of DAPI for identifying and counting microflora. Limnol Oceanogr 25:943-947

Riley GA (1957) Phytoplankton of the North Central Sargasso Sea. Limnol Oceanogr 2:252-270

> Rivkin RB, Legendre L (2001) Biogenic carbon cycling in the upper ocean: effects of microbial respiration. Science 291:2398-2400

Sommer U, Gliwicz ZM, Lampert W, Duncan A (1986) The PEG-model of seasonal succession of planktonic events in fresh waters. Arch Hydrobiol 106:433-471

Sommer U, Aberle N, Engel A, Hansen T and others (2007) An indoor mesocosm system to study the effect of climate change on the late winter and spring succession of Baltic Sea phyto- and zooplankton. Oecologia 150: 655-667

Søndergaard M, Williams PJLeB, Cauwet G, Riemann B and others (2000) Net accumulation and flux of dissolved organic carbon and dissolved organic nitrogen in marine plankton communities. Limnol Oceanogr 45:1097-1111

Tian RC, Deibel D, Thomson RJ, Rivkin RB (2003) Modeling of climate forcing on a cold-ocean ecosystem, Conception Bay, Newfoundland. Mar Ecol Prog Ser 262:1-17

Williams PJLeB, Morris PJ, Karl DM (2004) Net community production and metabolic balance at the oligotrophic ocean site, station ALOHA. Deep-Sea Res I 51: 1563-1578

Zubkov MV, Sleigh MA, Burkill PH, Leakey RJG (2000) Bacterial growth and grazing loss in contrasting areas of North and South Atlantic. J Plankton Res 22:685-711

Submitted: October 15, 2007; Accepted: March 19, 2008 Proofs received from author(s): May 8, 2008 